\title{
QUANTUM MECHANICAL DESIGN OF TWO LOGICAL FUNCTIONS MOLECULAR DEVICE
}

\author{
J. Tamulienè ${ }^{\mathrm{a}}$, A. Tamulis ${ }^{\mathrm{a}}$, A. Žiriakovienè ${ }^{\mathrm{a}}$, and A. Graja ${ }^{\mathrm{b}}$ \\ ${ }^{a}$ Institute of Theoretical Physics and Astronomy of Vilnius University, A. Goštauto 12, LT-01108 Vilnius, Lithuania \\ E-mail: gicevic@itpa.lt \\ ${ }^{\mathrm{b}}$ Institute of Molecular Physics, Polish Academy of Sciences, Smoluchowskiego 17, 60-179 Poznań, Poland
}

Received 21 March 2006

\begin{abstract}
Quantum mechanical investigations of isolate molecules and a bridge fragment are performed. Based on the investigation results, the design of two logical functions device was done. The investigation results indicate that the molecular device could be applied as logical YES and/or NOT functions. The extension of the concept of a molecular device is of interest for the growth of nanoscience and the development of nanotechnology, as well as the control of chemical reactions.
\end{abstract}

Keywords: molecular logical function, nanoscience, excited state, charge transfer, molecular device

PACS: $31.15 \mathrm{Ar}, 34.70 .+\mathrm{e}$

\section{Introduction}

In the last twenty years, the development of supramolecular chemistry has allowed the construction of simple molecular-level devices. The molecules may be used as devices because they operate via electronic and/or nuclear rearrangements and, like macroscopic devices, need energy to operate and the signals to communicate with the operator. The extension of the concept of a device to the molecular level is of interest, not only for the basic research, but also for the growth of nanoscience and the development of nanotechnology and, maybe, in the explanation of origin of life. Molecular-level devices find applications in information storage, display, and processing; in the long run, they are expected to lead to the construction of molecular-based (chemical) computers [1]. Moreover, deeper knowledge in this field allows one to bridge non-living and living matter.

A molecular memory devices are proposed and demonstrated for the data storage up to three bits (eight levels) per cell, in contrast to the standard one-bit-percell (two levels) technology [2]. The unique electronic properties of carbon nanotubes are used for the recognition capabilities of DNA [3]. Basing on various properties of molecules a lot of molecular switches are designed [4-7]. Helical peptide segments have often been employed in peptide-based molecular devices and materials due to their conformation changeability [8]. The
$\mathrm{R}-\mathrm{M}$ enzymes could be applied as unusual molecular motors that bind specifically to DNA and then move to the rest of the DNA through this bond complex [9]. In addition, Nishikawa et al. found that the insulating inorganic films obtained by catalytic chemical vapour deposition were quite effective in the protection of molecular devices against water and / or oxygen [10]. Peskin et al. propose to use the intramolecular electron and electronic energy transfer as a way of connection between the logical operations that are implemented on different molecules [11].

On the other hand, the concept of a macroscopic device can be extended to the molecular level by designing and synthesising (supra)-molecular species capable of performing several specific functions, i. e. designing materials to accomplish multiple performance objectives in a single system. Double function structurebattery materials for unmanned air-vehicle applications are reported by Thomas et al. [12]. Interestingly, cell membranes resembling periodic minimal surfaces have been observed in cytoplasmic organelles, such as mitochondria and chloroplasts, in which a variety of different transport processes occurs [13]. The dicyanamide anion, $[\mathrm{N}(\mathrm{CN}) 2]^{-}$, is shown to be a versatile building block for the assembly of coordination polymers which are components of molecular superconductors, magnets, and conducting/magnetic hybrid materials [14]. It is possible to extend the functions of the molecular devices. 


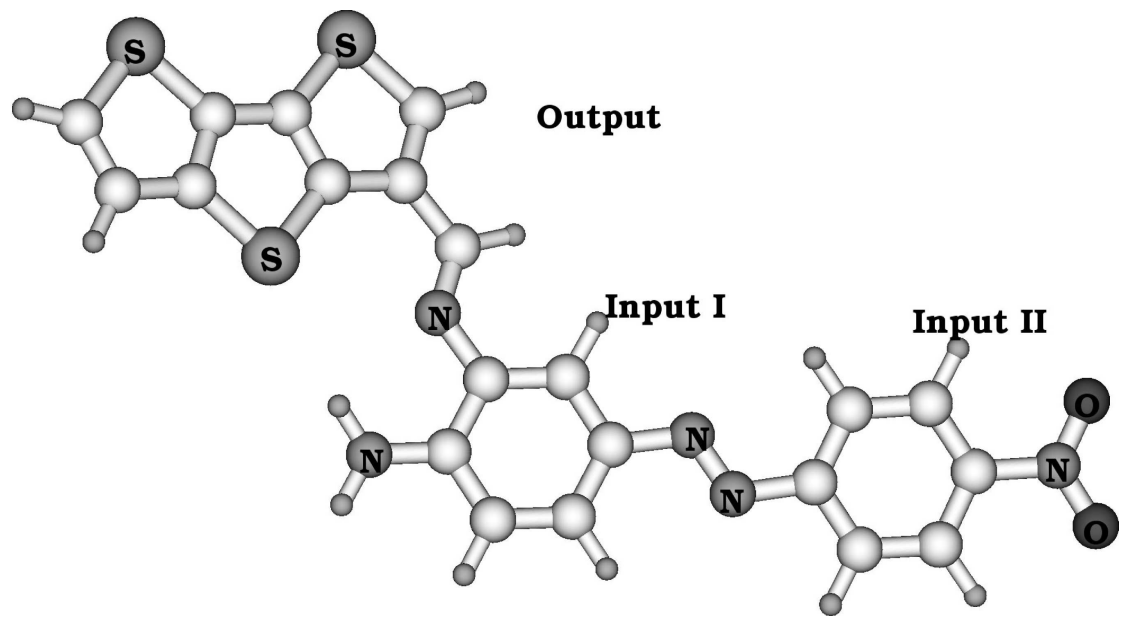

Fig. 1. Two logical functions molecular logical devices designed from the DO3 and dithieno[3,2-b:2',3'-d]thiophene molecules. The inputs and the output of the device are marked.

In this paper, we intend to exhibit that the same molecule could be applied as two different logical functions. The design of the two logical functions device is started from the system that could be used for implementation of molecular logical NOT or / and YES. It is possible to foresee that the application of the two logical functions materials allows us to minimize and accelerate the computation process. We believe that the multi-logical function materials could be present in a living organism as chemical reaction controlling, information coding and encoding, storage and usage devices.

\section{Problem formulation, investigation method, and results}

The design and investigation of the light-driven supermolecular logical devices based on the Disperse orange 3 (DO3) and dithieno[3,2-b:2',3'-d]thiophene (Thiophene) molecules were performed applying timedependent density functional theory (TD DFT) with a B3PW91 exchange-correlation functional and a 6-31G model [12-14]. The above molecules were joined with the $-\mathrm{CH}=\mathrm{N}-$ molecular bridge (Fig. 1). This bridge fragment is chosen not accidentally. It has been shown that the bridge fragments not only fix the orientation of the photoelectron donor and photoelectron acceptor molecules with respect to each other but also play a crucial role in the mediation of the electron transfer process by changing electronic properties of the excited state [15].

Firstly, a full geometry optimization was carried out for the isolated DO3 and Thiophene molecules applying B3PW91 method with different basis sets such as $6-31 \mathrm{G}, 6-311 \mathrm{G}, 6-311 \mathrm{G}^{* *}$. In all these investigations the convergence was achieved and the stationary point was found $[15,16]$. The geometries of the above molecules obtained applying B3PW91/6-311G** basis set exhibit a marked resemblance to the geometrical structure of the supermolecule obtained by B3PW91/6-311G and 6-31G. Moreover, we have compared the UV and visible spectra of the DO3 molecule obtained by TD B3PW91/6-31G, CIS HF/ 6-311G** methods with experimentally measured spectra of this molecule in hexane solution [17]. The performance of these methods is found to be good. Only a small systematic basis set dependent blue shift is obtained. The calculated spectrum of the dithieno[3,2b:2',3'-d]thiophene molecule looks like the absorption spectra of the Thiophene polymers and oligomers in benzene solution, i. e. the obtained maxima fit within the absorption region of these polymers and oligomers [18]. Thus, for quantum computation the quite relevant generalization follows that the TD B3PW91 method within $6-311 \mathrm{G}^{* *}, 6-311 \mathrm{G}$, or $6-31 \mathrm{G}$ is suitable for the investigations of DO3 and Thiophene, and should also be correct enough for the study of the derivatives that are designed from these molecules. Before we proceed any further, let us remember that the results obtained with the TD B3PW91 method within a 6-31G basis set coincide with those within $6-311 \mathrm{G}^{* *}$, i. e. the obtained result is not strongly dependent on the basis set therefore the charge transfer investigations are performed applying TD B3PW91 / 6-31G only.

The investigations of one-electron orbitals of the $\mathrm{CH}_{2}=\mathrm{NH}$ bridge fragment, DO3, and Thiophene molecules indicate that the orbitals do not interact (Fig. 2). However, the gap between HOMO and LUMO orbitals of $\mathrm{CH}_{2}=\mathrm{NH}$ is equal to 0.13 a. u. and that of the 


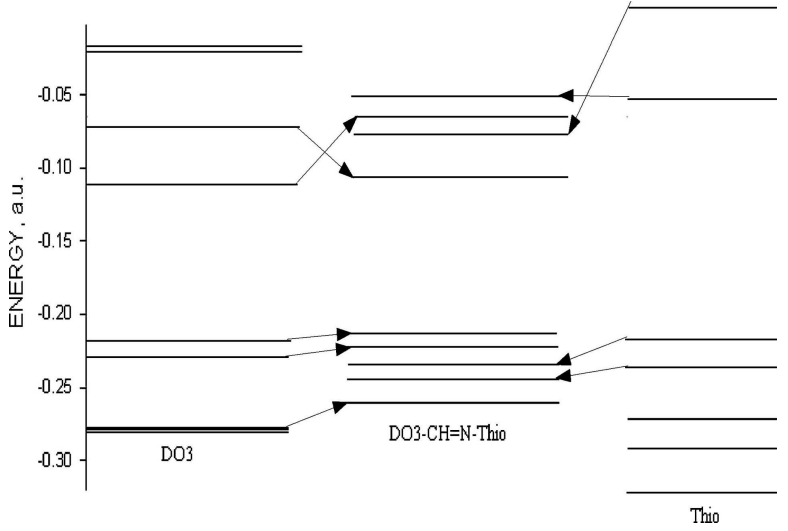

Fig. 2. Placement of one-electron orbitals of the DO3, thiophene molecules, and supermolecule consisting of these ones joined with $-\mathrm{CH}=\mathrm{N}-$ bridge fragment.

DO3 and Thiophene are 0.11 and 0.16 a.u. respectively. The results indicate that the HOMO-LUMO orbitals of the $\mathrm{CH}_{2}=\mathrm{NH}$ bridge are in-between the photoactive molecular ones. Thus, the mixing (shift) of supermolecular orbitals in the case of the $-\mathrm{CH}=\mathrm{N}-$ bridge fragment takes place. Moreover, the LUMO+1 orbital of the supermolecule with $-\mathrm{CH}=\mathrm{N}-$ fragment is partly composed of the orbital of this bridge. Thus, the excitation from the DO3 to Thiophene takes place that is important for the design of two logical functions devices.

Without going into formal details, let us consider this supermolecule as a molecular device. In our notation the combinations of all possible excitations and charge transfer processes should correspond to logical function results. To exhibit that the molecule could be applied as two logical functions device, the part of this supermolecule consisting of Thiophene with the bridge fragment was assumed as output. On the other hand the other part of the supermolecule consisting of DO3 is divided into two parts: (i) $\mathrm{Ph}-\mathrm{NH}_{2}$ and (ii) $-\mathrm{N}=\mathrm{N}-\mathrm{Ph}-\mathrm{NO}_{2}$. These are two inputs. The charge changes during excitations are obtained by taking the Mulliken atomic charge differences in the excited states and the ground state. The obtained atomic charge changes describe the electron excitation process qualitatively, but allow us to compare electron density redistribution in the various excited states. The most important differences between the charge located on the various fragments of the investigated molecule are presented in Table 1.

Let us assume that logical 1 is on the output or inputs when an additional negative charge on the part of the supermolecule is present, while logical 0 is assumed when the additional positive charge is present on it. Let us imagine that the supermolecule is excited by certain wavelength. As an example, in the second excited state the additional positive charge is obtained on the $\mathrm{Ph}-\mathrm{NH}_{2}$ (Input I) and the Thiophene (Output) fragments (Table 1). On the other hand in the VI excited state the additional negative charge accumulates on the both above-mentioned fragments (Table 1). It implies that in both cases we have the same logical values on input and output. Hence, the logical function truth table is the following:

\section{Input I Output

$0 \quad 0$ \\ $1 \quad 1$}

It corresponds to logical YES function.

When we are interested in having the other logical functions, then $\mathrm{Ph}-\mathrm{NO}_{2}$ and Thiophene fragments of this supermolecule could be accepted as the input and the output respectively. In the III excited state, the additional negative charge is obtained on the input, while the positive charge accumulates on the Thiophene fragment (Table 1). It implies that on input we have logical 1 , while on output logical 0 is obtained. In the $V$ excitation state, the additional negative and positive charge placements are contrary in comparison to those in the III excited state (Table 1). Hence, in this state logical 1 is on output, while logical 0 is present on input. In this case it is possible to obtain the other truth table:

$\begin{array}{cc}\text { Input II } & \text { Output } \\ 1 & 0 \\ 0 & 1\end{array}$

The above truth table represents logical NOT functions.

Table 1. Differences between the charge located on various fragments of the investigated molecules in excited states and in the ground state. The results are obtained by applying B3PW91 TD method within the 6-31G basis set.

\begin{tabular}{cccc}
\hline Excited state & Output (Thiophene fragment) & Input $\mathrm{I}\left(\mathrm{Ph}-\mathrm{NH}_{2}\right.$ fragment $)$ & Input II $\left(\mathrm{Ph}-\mathrm{NO}_{2}\right.$ fragment $)$ \\
\hline$I I$ & 0.18 & 0.49 & -0.67 \\
$I I I$ & 0.83 & -0.04 & -0.8 \\
$V$ & -0.17 & -0.09 & 0.26 \\
$V I$ & -0.51 & -0.12 & 0.6 \\
\hline
\end{tabular}


It is evident that our designed supermolecule could be applied as YES and NOT logic functions. Hence, the two simplest logical functions molecular device is designed.

\section{Conclusion}

Based on the investigation results, it is evident that the molecules could be applied as two logical functions molecular device, i. e. the same molecule could realise several logical functions. The study does not answer the question how to design the other logical functions such as OR and AND, how to choose the photodonor, the photoacceptor molecules, and the bridge fragment so that the electron transfer process should be successful, because various phenomena could influence this transfer. However, it is evident that the investigated supramolecule could be used as the two logical functions device.

\section{Acknowledgements}

The work was funded via PACE (Programmable Artificial Cell Evolution), a European Integrated Project in the EU FP6 IST-FET Complex Systems Initiative and partly by the Lithuanian State Science and Studies Foundation. We are grateful to Poznan's Supercomputing and Networking Centre for the possibility to use CRAY and Gaussian98 package as well as Supercomputing Centre of Vilnius Gediminas Technical University for the possibility to use their cluster and GAMESS package.

\section{References}

[1] V. Balzani, Photochemical molecular devices, Photochem. Photobiol. Sci. 2(5), 459-476 (2003).

[2] Ch. Li, W. Fan, B. Lei, D. Zhang, S. Han, T. Tang, X. Liu, Z. Liu, S. Asano, M. Meyyappan, J. Han, and Ch. Zhou, Multilevel memory based on molecular devices, Appl. Phys. Lett. 84(11), 1949-1951 (2004).

[3] K.A. Williams, P.T.M. Veenhuizen, B.G. de la Torre, R. Eritja, and C. Dekker, Towards DNA-mediated self assembly of carbon nanotube molecular devices, AIP Conf. Proc. 633(1), 444-448 (2002).

[4] A. Yassar, F. Garnier, H. Jaafari, N. Rebière-Galy, M. Frigoli, C. Moustrou, A. Samat, and R. Guglielmetti, Light-triggered molecular devices based on photochromic oligothiophene substituted chromenes, Appl. Phys. Lett. 80(23), 4297-4299 (2002).
[5] B. Nurnberg, W. Togel, G. Krause, R. Storm, E. Breitweg-Lehmann, and W. Schunack, Non-peptide G-protein activators as promising tools in cell biology and potential drug leads, Eur. Med. Chem. 34(1) 5-30 (1999).

[6] S. Giordani, M.A. Cejas, and F.M. Raymo, Photoinduced proton exchange between molecular switches, Tetrahedron 60(48), 10973-10981 (2004).

[7] J.Y. Liu, A.H. Flood, and J.F. Stoddart, Thermally and electrochemically controllable self-complexing molecular switches, Am. Chem. Soc. 126(30), 9150-9151 (2004).

[8] S.S. Pennadam, K. Firman, A. Cameron, and D.C. Górecki, Protein-polymer nano-machines. Towards synthetic control of biological processes, J. Nanobiotechnol. 2(8) 1-7 (2004).

[9] T. Nishikawa and T. Mitani, A new approach to molecular devices using SAMs, LSMCD and Cat-CVD, Sci. Technol. Adv. Mater. 4(1), 81-89 (2003).

[10] U. Peskin, M. Abu-Hilu, and Sh. Speiser, Approaches to molecular devices based on controlled intramolecular electronic energy and electron transfer. Electron transfer rates through flexible molecular bridges by a time-dependent super exchange model, Opt. Mater. 24(1-2) 23-29 (2003).

[11] H.H. Heinze, A. Gorling, and N.J. Rosch, An efficient method for calculating molecular excitation energies by time-dependent density-functional theory, Chem. Phys. 113(6), 2088-2099(2000).

[12] P.J. Thomas, M.A. Qidwai, P. Matic, and R.K. Everrett, Composite materials with multifunctional structurepower capabilities, in: American Society for Composites (ASC) 16, Technical Conference Proceedings CDROM, eds. M.W. Hyer and A.C. Loos, Virginia Tech., Blacksburg, VA, September 9-12, 2001.

[13] S. Torquato, S. Hyun, and A. Donev, Multifunctional composites: Optimizing microstructures for simultaneous transport of heat and electricity, Phys. Rev. Lett. 89(26), 266601-1-4 (2002).

[14] M.L. Balevicius, J. Tamuliene, and A. Tamulis, Role of excited states on cis-trans isomerization of disperse orange 3 molecule, Lithuanian J. Phys. 40(6), 387-393 (2000).

[15] J. Tamuliene, M.-L. Balevicius, and A. Tamulis, How has the bridge fragment choosen to design of charge transfer molecular device?, Structural Chem. 15(6) 579-585 (2004).

[16] M.L. Balevicius, J. Tamuliene, and A. Tamulis, Influence of various substituents for isomerization process of azo-dye, Lithuanian J. Phys. 41(2), 83-88 (2001).

[17] A. Tamulis, J. Tamuliene, M.L. Balevicius, and Z. Rinkevicius, $A b$ initio quantum chemical search of per linear transition state of azo-dye molecules and design of molecular logical machines, Nonlinear Opt. 27, 481-488 (2001).

[18] J. Nunzi, private communication. 
[19] J. Seixas de Melo, H.D. Burrows, M. Svensson, M.R. Andersson, and A.P. Monkman, Photophysics of thiophene based polymers in solution: The role of nonradiative decay processes, J. Chem. Phys. 118(3), 1550-1556 (2003).

\title{
DVIEJŲ LOGINIŲ FUNKCIJU MOLEKULINIO PRIETAISO MODELIAVIMAS KVANTINĖS MECHANIKOS METODAIS
}

\author{
J. Tamuliené ${ }^{\mathrm{a}}$, A. Tamulis ${ }^{\mathrm{a}}$, A. Žiriakoviene ${ }^{\mathrm{a}}$, A. Graja ${ }^{\mathrm{b}}$ \\ ${ }^{a}$ VU Teorinès fizikos ir astronomijos institutas, Vilnius, Lietuva \\ ${ }^{\mathrm{b}}$ Molekulinès fizikos institutas, Poznanè, Lenkija
}

\section{Santrauka}

Atlikus supermolekulès, sudarytos iš DO3 ir ditieno[3,2-b:2', $3^{\prime}$-d]tiofeno (tiofeno) molekulių, sujungtu $-\mathrm{CH}=\mathrm{N}-$ tiltelio fragmentu, kvantinès chemijos teorinius tyrimus, teigiama, kad ji gali būti panaudojama kaip dviejų loginių funkcijų NE ir TAIP molekulinis prietaisas. Remiantis tyrimų rezultatais parodyta šios su- permolekulès molekulinių orbitaliu prigimtis ir numatyta, kad, atitinkamai sužadinus, galima elektronų pernaša nuo skirtingų DO3 molekulès fragmentų ant tiofeno molekulès. Pateiktos rastos pernešamo krūvio vertès, kurios patvirtina aukščiau aprašytas prielaidas. Būtent ši pernašos savybè yra panaudota modeliuojant dvieju loginių funkcijų prietaisą. 